\title{
Domestic Violence Against Women Rising During Covid-19 Pandemic : A Sociological Study
}

\author{
Sartaj Ahmad ${ }^{1}$, Bhawana Pant ${ }^{2}$, Monika Gupta $^{2}$, Alka Singh $^{3}$, Prateek Kishor ${ }^{3}$ \\ ${ }^{1}$ Associate Professor (Medical Sociology), Department of Community Medicine, Subharti Medical College,

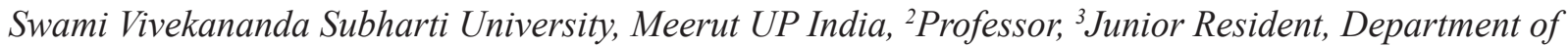 \\ Community Medicine, Subharti Medical College, Meerut UP India
}

\begin{abstract}
Violence against women within the family is a global phenomenon. No society can claim to be free of such violence. The degree of violence differs according to the socio economic condition of the society. Women in Indian society are victims of ill-usage, humiliation, torture and exploitation for as long as written records of structure and family life are accessible. These records are replete with incidents of abduction, rape, murder and torture of girls. Women themselves tolerated all this in the name of their spiritual values and socio-cultural attitudes, because the cases of wife-battering, rapes, kidnappings and abductions, intra-familial murders, dowry-deaths, eve-teasing and molestation, etc., were reported.
\end{abstract}

Keywords:- Domestic violence, Women, Covid-19, Human Rights

\section{Introduction}

The women are the soul of our community they are self build and self trained human responsible for the morale development of their children, inspiration for the family and an example for the community to follow. Women as a community member are an example of love, friendliness, inspiration and the best worker. These are the normal roles and responsibilities performed by the women community around the evident than the violence to which a woman is subjected in her domestic setup. In spite of fifty percent of the population on the world wide, women were not in equal status with men. In a

\section{Corresponding Author:}

Dr. Alka Singh,

Junior Resident, Department of Community

Medicine, Subharti Medical College, Swami

Vivekananda Subharti University, Meerut UP India.

Email-alkasingh24593@gmail.com traditional form, status and social role of the women in every society and specific Indian society have been weaker than men. A woman is never appreciated for her indirect participation in the strong development and in the progress of her children, family or external community.

'Domestic Violence' is defined in The Protection of Women from Domestic Violence Act (India, 2005) as "any act of commission or conduct resulting in physical, verbal, emotional, sexual and economic abuse" and this can range from calling names, insulting, humiliating, controlling behaviour, physical violence to sexual violence. ${ }^{[1]}$

When the world was facing to cope with the Corona Virus Disease of 2019 (COVID-19) crisis phase I, many countries took resort to 'stay at home' orders. India being one such country, ordered a complete Lockdown nationally. Though steps such as these are essential to contain the global pandemic, this 'Hobsons choice' has brought along some unintended 
negative consequences. One of them was Domestic Violence against women.

The incidents of violence against women have increased worldwide since the lockdowns were implemented, The hash tag anti domestic violence during epidemic was searched more than 3000 times in Chinese social media. As per the statistics released by the National Commission for Women (NCW) India in early April 2020 there has been lot of number increased in complaints related to violence against women after the nationwide lockdown was imposed in March 2020. ${ }^{[2]}$

\section{Causes of Domestic violence against Women} during Covid-19

The causation of Domestic violence during Covid-19 was multifaceted, precipitated through multiple, interdependent causes like stress due to physical confinement, economic disruption, slowed down businesses, possible unemployment, scarcity of basic provisions, limited social support. Loss of income, especially for males leads to lesser control over economic security and thereby making them exert more control on their partners, this scenario is worse if female spouse is employed and male is unemployed. Unemployment for female also mean being dependent on male spouse, loss of social ties and being locked up with perpetrator 24 by 7 , which again makes them vulnerable to violence. Rise in Domestic violence could also be attributed to household work related disparity. India being a patriarchal society, domestic work is primarily considered women's job. Absence of domestic help and people thrown into close quarters, increases workload and cabin fever ensues, adding fuel to the ongoing friction between the couple and results in increased chances of Domestic violence. In addition to above, among the families affected by substance use disorder, COVID 19 has worsened the Domestic violence. The stress of economic instability itself has resulted in increased consumption of alcohol, thereby increasing domestic violence independently.

During lockdown, the perpetrator might inflict violence on the spouse demanding to fulfill his alcohol consumption needs or might consume alcohol at home, in presence of his family members, as the liquor outlets are closed. In both above scenarios domestic violence worsens. Sexual violence is also likely to increase during lockdown. India noted a surge of porn usage and sale of condoms and sex toys, reflecting increase in sexual activity thereby indirectly indicating increase in chances of sexual rights violation.

Crime, atrocity and violence against woman are a revelation of the factual disproportionate power relation among man and woman, which lead to the domination of a woman's fuller advancement. Violence in the domestic spare is usually committed by them who are or who have been, in a position of trust and intimacy and power- husband's father, brother, uncle sons or other relatives. It does not mean that women are not violent but their actions account for a small percentage of domestic violence.

The criminals, atrocious abuser and the abused are tied together because of emotional, physical, biological, familial, residential and financial ties, and are often their intimate partners. Perpetrators of domestic violence seek power and control over their survivors. The factors which contribute to the continued prevalence of violence are mainly woman's lack of deprivation of approach to legal information, to provide support or safeguard and also the lack of laws that protect woman against violence. The existing laws have not been reformed and existing public authorities dealing with the same laws also failed in due adding awareness and in implementing existing laws. In spite of Constitutional guarantees and legal protection there is a rise on the trend of committing offenses against women and domestic 
violence is one of them. Domestic violence is a pattern of abusive behavior in any relationship that is used by one partner to gain or maintain power and control over another partner. Domestic violence can happen to anyone regardless of race, age, caste, religion or gender. It is a Pattern of behavior characterized by the misuse of power and promise by one person against another who generally happens to be in an intimate or blood relationship. Domestic violence is not typically a singular event and it is not limited to only physical aggression. Rather, it is the methodical use of threats, ignominy and physical violence by someone who seeks power and control over his intimate partner.

\section{Domestic violence may be of different kinds like} physical violence, sexual abuse, emotional abuse, economic deprivation and stalking.

i. Physical violence is the intentional use of physical force for causing injury, harm, disability or death to the victims. Physical violence is the easiest to recognize and understand than any other types of domestic violence. Hitting, shoving, beating, restraining, kicking, scratching, pushing, slapping, punching or uses of a weapon are the few examples of physical violence.

ii. Sexual abuse generally refers to the use of physical force to compel a person to engage in a sexual act against his or her will or due to one's inability to communicate unwillingness to engage in the act owing to underage, immaturity, illness, disability or the influence of alcohol. Unwanted touching, raping, denying the victims from protection against sexually transmitted diseases, sexual exploitation through photography or prostitution, treating the victim like a sexual object, forcing the victim to have an abortion, engaging in an extramarital relationships are also the few examples of sexual violence.

iii. Emotional abuse can include humiliating the victim privately or publicly or doing something to make the victim feel socially or psychologically maligned or embarrassed using degrading language, criticism, screaming, refusing to talk and so on. Insulting the victim in the presence of children, other member of the family and relatives, blaming her for everything that goes wrong in the family, charging her frequently on small and negligible issues, making her feel guilty for no fault of her, calling her names, giving her threat of divorce, treating her like a servant, keeping a strict watch on her movements, prohibiting her from meeting her friends and relatives, prohibiting her from expression of her view on family matters, suspecting her for extramarital relations, using ugly and insulting language for her parents, insulting her for housekeeping, demeaning her family background, criticizing her for lacking intelligence are also the few examples of emotional abuse.

iv. Money becomes a tool by which the abuser can further control the victim. Economic abuse refers to depriving a person from his/her own money or to which he/she is entitled. Such type of abuse generally includes acts such as the denial of funds, refusal to contribute financially, denial of food and basic needs and controlling access to health care, employment and so on. Many countries have reported an increase in domestic violence and intimate partner violence attributed to lockdowns amid the COVID-19 pandemic. Financial insecurity, stress, and uncertainty have lead to increased aggression at home, with abusers able to control large amounts of their victims' daily life. ${ }^{[3]}$

v. Stalking generally refers to repeated misbehavior with the intention of inducing fear in the mind of the victim. It generally includes behavior like repeated phone calls, emails or letters, watching, spying, tracking and threatening someone or his/her loved ones. Assaulting or threatening to assault verbally, physically or sexually is also a kind of stalking. Although emotional and financial abuses are not directly defined as criminal acts, but indirectly they may cause 
harms which may amount to criminal acts.

\section{Supports and Help to Victims}

The National Legal Service Authority ( NLSA) reports to Hon'ble Justice N.V. Ramana of the Supreme Court found that there were 144 cases of domestic violence registered during $1^{\text {st }}$ phase of lockdown due to the pandemic in Uttrakhand, 79 in Haryana, 63 in Delhi, 35 in Ghaziabad and as many as 573 in Noida. Helpline in Ghaziabad found that they getting an average of 35 calls a day which was more than the usual five calls they would get on a normal day before lockdown.

The national commission for women (NCW) installed a special WhatsApp number to report domestic violence incidents, as it saw an immediate rise in cases when India went into Lockdown. In the very first week, NCW recorded more than a twofold increased in a number of domestic violence cases and sexual assaults.

Ms Smiriti Irani, Minister for Women and child development directed to her staff to ensure that reporting of domestic violence should be encouraged and digital governance should be strict to ensure women safety.

Ms Rekha Sharma, a Chairperson of the NCW said that there were a large number of cases found from UP, Bihar, Haryana, and Punjab.

Dr Trupti, Assistant professor of Tata Institute of Social Sciences told that the real number of violence against women during the pandemic would not give the real picture as many would not complain when the abuser was present in the house.

The Delhi Legal Service Authority (DLSA) has came up with the idea of helping victims to report abuse. It has authorized Mother Dairy outlets that are open seven days in a week even during the lockdown and were frequented by women to buy milk and its products to become centers where women can discreetly report the abuse they are subjected to. Then, the owner of the Dairy will issue an alert to the legal authorities or the police. Correspondingly, Chemist shops had also been authorized to take complaints.

\section{Conclusion}

In India, the women are facing violence from female fetus to early marriages, domestic violence to dowry death without any respite in their life time. From the above review, it may be said that there are different factors responsible for domestic violence against women such as illiteracy, poverty, traditional outlook and poor implementation of laws. But solving of the problem of domestic violence is an imminent necessity not only to end gender discrimination but also to achieve the goal of human rights in our society.

Acknowledgement- none

Conflict of Interest - none

Source of Funding- none

Ethical Approval- taken from institutional ethical committee

\section{References}

1. Kaur R, Garg S. Addressing domestic violence against women: an unfinished agenda. Indian $\mathrm{J}$ Community Med. 2008 Apr;33(2):73-6.

2. National Commission For Women. 2020Apr; Available from: www.ncw.nic.in

3. Writer G. Covid-19 Pandemic \& The SocioEconomic \& Political Impact On Women [Internet]. Feminism In India. 2020 [cited 2021Nov29]. Available from: https:// feminisminindia.com/2020/04/29/covid-19pandemic-socio-economic-political-impactwomen/ 